\title{
Effects of cross-linked high-molecular-weight hyaluronic acid on epidural fibrosis: experimental study
}

\author{
Semra Isık, MD, M. Özgür Taşkapılıoğlu, MD, Fatma Oz Atalay, MD, and Seref Dogan, MD \\ Department of Neurosurgery, Uludag University Medical School, Bursa, Turkey
}

OBJECT Epidural fibrosis is nonphysiological scar formation, usually at the site of neurosurgical access into the spinal canal, in the intimate vicinity of and around the origin of the radicular sheath. The formation of dense fibrous tissue causes lumbar and radicular pain. In addition to radicular symptoms, the formation of scar tissue may cause problems during reoperation. The authors aimed to investigate the effects of cross-linked high-molecular-weight hyaluronic acid $(\mathrm{HA})$, an HA derivative known as HA gel, on the prevention of epidural fibrosis by using histopathological and biochemical parameters.

METHODS Fifty-six adult female Sprague-Dawley rats were evaluated. The rats were divided into 4 groups. Rats in the sham group $(n=14)$ underwent laminectomy and discectomy and received no treatment; rats in the control group $(n=$ 14) underwent laminectomy and discectomy and received $0.9 \% \mathrm{NaCl}$ treatment in the surgical area; rats in the $\mathrm{HA}$ group $(n=14)$ received HA treatment at the surgical area after laminectomy and discectomy; and rats in the HA gel group $(n=$ 14) underwent laminectomy and discectomy in addition to receiving treatment with cross-linked high-molecular-weight HA in the surgical area. All rats were decapitated after 4 weeks, and the specimens were evaluated histopathologically and biochemically. The results were statistically compared using the Mann-Whitney U-test.

RESULTS Compared with the sham and control groups, the HA and HA gel groups showed significantly lower fibroblast cell density and tissue hydroxyproline concentrations $(p<0.05)$. There was statistically significant lower dural adhesion and foreign-body reaction between the control and HA gel groups $(p<0.05)$. Granulation tissue and epidural fibrosis were significantly lower in the HA and HA gel groups compared with the sham group $(p<0.05)$. There were no significant differences in any histopathological parameters or biochemical values between Groups 3 and $4(p>0.05)$.

CONCLUSIONS Cross-linked high-molecular-weight HA had positive effects on the prevention of epidural fibrosis and the reduction of fibrotic tissue density. The efficacy of this agent should also be verified in further experimental and clinical studies.

http://thejns.org/doi/abs/10.3171/2014.10.SPINE131147

KEY WORDS cross-linked high-molecular-weight hyaluronic acid; epidural fibrosis; laminectomy

$\mathbf{P}$ OSTOPERATIVE epidural fibrosis is a normal biological response after laminectomy. Fibrosis is the replacement of epidural fat with fibrotic tissue, which binds the dura and the nerve roots to the anterior and posterior structures. ${ }^{12}$ Because of the risk of dural tears, bleeding, nerve root injury, and iatrogenic instability, reoperation is difficult in such cases. ${ }^{12}$

Many surgical techniques and several materials developed through various experimental research models have been proposed to correct epidural fibrosis, including free or pedicle fat graft, ${ }^{4}$ dermis, ${ }^{5}$ ligamentum flavum,,${ }^{33}$ dura mater, ${ }^{35}$ amniotic membrane, ${ }^{9}$ gelatin foam sponge, ${ }^{20}$ mi- crofibrillar collagen ${ }^{20}$ Spongostan, ${ }^{25}$ Silastic membranes, ${ }^{13}$ Vicryl (polyglactin 910) mesh, ${ }^{31}$ polylactic acid glue, ${ }^{26}$ hemostatic agents, ${ }^{15,43}$ expanded polytetrafluoroethylene membrane, $, 13,27$ polymethylmethacrylate or otogen laminar bone graft replacement, ${ }^{23}$ carboxymethylcellulose, ${ }^{14,38}$ polyethylene oxide, ${ }^{38}$ sodium hyaluronan, ${ }^{22,43}$ topical high-molecular-weight hyaluronan, 1,22,30,42,43 methylprednisolone, triamcinolone, prednisolone, dexamethasone, ${ }^{6,36}$ antiinflammatory agents, ${ }^{6,20}$ colchicine, ${ }^{32}$ citicoline, ${ }^{40} \mathrm{CO}_{2}$ laser ${ }^{10}$ and low-dose external-beam radiation therapy. ${ }^{17}$

Hyaluronic acid (HA) is a heteropolysaccharide formed by binding repetitive disaccharide units of D-glucuronic

ABBREVIATIONS HA = hyaluronic acid; TNF = tissue necrosis factor

SUBMITTED January 1, 2014. ACCEPTED October 6, 2014.

INCLUDE WHEN CITING Published online November 14, 2014; DOI: 10.3171/2014.10.SPINE131147.

DISCLOSURE The authors report no conflict of interest concerning the materials or methods used in this study or the findings specified in this paper. This work was supported by Uludag University Scientific Project Programme grant HDP(T)-2012/50. 
acid and $N$-acetyl-glucosamine with $\beta-4$ bindings, which naturally occurs in the soft tissues and extracellular matrix of all vertebrates. ${ }^{45}$ It is a critical regulator of many biological events, such as embryonic development, tissue organization, wound healing, and angiogenesis. HA has a preserved structural homology across species; therefore, it is highly biocompatible and does not cause a foreign-body reaction. ${ }^{19}$ Exogenous HA inhibits fetal fibroblast proliferation distinctively. Data indicate that during development and the first stages of tissue repair, a relatively high concentration of HA in the extracellular space would partially limit the extracellular matrix and collagen deposition. ${ }^{39}$ This has suggested that HA has effective roles in preventing fibrosis and scar formation and during the early stages of wound healing. Because HA is soluble in water at room temperature and has short residence time in tissue, it is not convenient for clinical practice.

Cross-linked high-molecular-weight HA (Hyalobarrier, Synvisc, Genzyme) is derived through an internal autocross-linking reaction of pure HA oligomers without exposure to any chemical substance foreign to the native HA structure to avoid possible adverse effects. ${ }^{29,37}$ This crosslinked high-molecular-weight HA is referred to throughout the paper as "HA gel." Compared with HA, HA gel is effective in retarding hydrolytic degradation, has less viscosity, and resides in the tissue longer (7 days). ${ }^{7,34,44}$ This HA derivative has been shown to be a potent inhibitor of tumor necrosis factor- $\alpha(\mathrm{TNF} \alpha)$ and TNF $\beta{ }^{7,8} \mathrm{HA}$ gel is currently used as an adjuvant therapy to prevent postoperative adhesions after laparotomic, laparoscopic, and hysteroscopic abdominopelvic surgical procedures. ${ }^{29}$

The purpose of this study was to investigate the effects of HA gel on the prevention of postoperative fibrosis and neural element adhesions.

\section{Methods}

\section{Surgical Procedure}

Sixty female Sprague-Dawley rats, weighing an average of 250-300 g, were used for this study. The protocol for the care and use of these rats was approved by the ethics committee of Animal Resources of Uludag University.

For prophylaxis, a single dose of $20 \mathrm{mg} / \mathrm{kg}$ cefazolin sodium (Cefozin, Bilim Ilaç) was injected intraperitoneally into each rat 30 minutes before the operation. Intramuscular anesthesia was induced with $70 \mathrm{mg} / \mathrm{kg}$ ketamine hydrochloride (Ketalar, Parke-Davis, Eczacıbaşı) and 10 $\mathrm{mg} / \mathrm{kg}$ xylazine hydrochloride (Rompun, Bayer). The rats were fixed in the prone position, and the surgical field was prepared by scrubbing it with $4 \%$ chlorhexidine soap (Klorheksol Scrub, Drogsan) for 10 minutes and disinfecting with povidone iodine solution (Isosol, Merkez Laboratories). The surgical area was covered with sterile blankets and draped. A midline skin incision approximately $4 \mathrm{~cm}$ in length was made from L-4 to L-7 to expose the spinous processes, and the L5-6 level was determined. The paraspinous muscles were dissected bilaterally. A dorsal total laminectomy at the L5-6 level was performed by the same neurosurgeon using an operative microscope (OPMI I, CARL ZEISS) with a drill (Micromot 50/E, Proxxon). After exposing the posterolateral aspect of the right side of the L5-6 disc, a 22-gauge needle was inserted to induce disc injury. In the sham group, laminectomy was performed and the disc injury was induced. In the control group, laminectomy and disc injury were performed, and $0.1 \mathrm{ml}$ of saline was applied to the epidural space. In the $\mathrm{HA}$ and HA gel groups, $0.1 \mathrm{ml}$ of HA and HA gel, respectively, was applied to the epidural space to cover the laminectomy defects. The wounds were closed in layers in a routine manner after attaining hemostatic control.

After recovery, the animals were evaluated in terms of their general medical condition and neurological status; then, they were allowed cage activity.

\section{Preparation of Specimens}

Four weeks after the surgery, all the rats were killed by intraperitoneal administration of high-dose (75-100 mg/ $\mathrm{kg}$ ) thiopental sodium (Sodium Pentothal). After examining the tissues for infection, the spinal column was removed en bloc from L-1 to L-7. The specimens were fixed in $10 \%$ buffered formaldehyde solution. After 2 days, they were immersed in a decalcification solution (equal amounts of $10 \%$ formic acid and $8 \% \mathrm{HCl}$ ) for 3 days for decalcification. After the decalcification procedure, the specimens were cut down to the laminectomy site, transverse to the spinal cord and with a thickness of $2 \mathrm{~mm}$. These tissues were processed according to routine tissue-processing techniques. Serial sections of $3 \mu \mathrm{m}$ were obtained from paraffin blocks by microtome (Leica RM 2145) and stained with H\&E and Masson's trichrome. Any animal with an intraoperative dural tear, a nerve root injury, any postoperative infection, and/or a hematoma was excluded from the study.

\section{Histopathological Examination}

All tissue samples were evaluated by a blinded observer. Each section was evaluated by an experienced histopathologist using a light microscope and was scored for the extent of the fibrosis, dural adhesion, foreign-body reaction, granulation tissue, inflammation, medulla spinalis retraction, and density of fibroblasts.

The dural adhesion parameters were evaluated according to the criteria proposed by He et al. ${ }^{18}$ Fibroblast cell density was calculated in each field at $\times 40$ magnification, according to the classification system proposed by Hinton et al. (see Table 1 for a summary of the grading schemes). ${ }^{19}$

\section{Biochemical Analysis}

The tissues were subjected to acid hydrolysis in $12 \mathrm{~N}$ $\mathrm{HCl}$ for 18 hours at $105^{\circ} \mathrm{C}$. Hydroxyproline was converted to pyrrole-2-carboxylic acid by oxidizing the samples with $20 \%$ chloramine-T and by incubating them for 10 minutes at room temperature. Ehrlich's reagent ( $p$-dimethylaminobenzaldehyde) was added and incubated at $50^{\circ} \mathrm{C}$ for 90 minutes. The optical density was read by spectrophotometry at $560 \mathrm{~nm}$. Standard 4-hydroxyproline (Sigma Chemical Co.) was used to generate a standard curve, and values are expressed as $\mu \mathrm{g} / \mathrm{g}$ wet tissue.

\section{Statistical Analysis}

Statistical analysis was performed using SPSS (version 22.0, IBM). A nonparametric Kruskal-Wallis test was 
TABLE 1. Summary of histopathological evaluation

\begin{tabular}{|c|c|c|c|c|c|}
\hline \multirow[b]{2}{*}{ Group } & \multicolumn{5}{|c|}{ Grade } \\
\hline & $\begin{array}{l}\text { Medulla Spinalis } \\
\text { Retraction* }\end{array}$ & Epidural Fibrosis* & Dural Adhesion† & $\begin{array}{l}\text { Granulation } \\
\text { Tissue* }^{*}\end{array}$ & $\begin{array}{c}\text { Fibroblast Cell } \\
\text { Density } \ddagger\end{array}$ \\
\hline \multicolumn{6}{|l|}{ Sham } \\
\hline Median & 0 & 2 & 1.5 & 1 & 2 \\
\hline Range & $0-2$ & $1-3$ & $0-3$ & $1-2$ & $2-3$ \\
\hline \multicolumn{6}{|l|}{ Control } \\
\hline Median & 0.5 & 2 & 3 & 1 & 2 \\
\hline Range & $0-2$ & $1-2$ & $1-3$ & $0-2$ & $1-3$ \\
\hline \multicolumn{6}{|l|}{$\mathrm{HA}$} \\
\hline Median & 0 & 1 & 0.5 & 0.5 & 1 \\
\hline Range & 0 & $0-2$ & $0-2$ & $0-1$ & $1-2$ \\
\hline \multicolumn{6}{|l|}{ HA gel } \\
\hline Median & 0 & 1 & 1 & 1 & 1 \\
\hline Range & $0-1$ & $0-2$ & $0-2$ & $0-1$ & $1-2$ \\
\hline \multicolumn{6}{|l|}{ Overall } \\
\hline Median & 0 & 2 & 2 & 1 & 2 \\
\hline Range & $0-2$ & $0-3$ & $0-3$ & $0-2$ & $1-3$ \\
\hline
\end{tabular}

* Epidural fibrosis extension, foreign-body reaction, granulation tissue, inflammation, and medulla spinalis retraction grading criteria: Grade 0 , absent; Grade 1, minimal; Grade 2, moderate; Grade 3, extensive.

$\dagger$ Dural adhesion grading scale: Grade 0, no scar tissue or fibrosis on the dura mater; Grade 1, only thin fibrous bands observed between dura mater and scar tissue; Grade 2, continuous adherence observed in less than two-thirds of the laminectomy site; Grade 3, large scar tissue affecting more than two-thirds of the laminectomy site, or the adherence extends to the nerve roots.

$\ddagger$ Fibroblast cell density was calculated in each field at $\times 40$ magnification according to the classification devised by Hinton et al.: Grade 1 , fewer than 100 fibroblasts in each field; Grade 2, 100-150 fibroblasts in each field; Grade 3, more than 150 fibroblasts in each field.

used to determine the statistical significance of the epidural fibrosis extension, foreign-body reaction, granulation tissue, inflammation, medulla spinalis retraction, dural adhesion, and fibroblast cell density among groups, while the Mann-Whitney U-test was used to assess the subgroup differences. The Cohen kappa coefficient was performed to analyze interobserver agreement. Additionally, the 2-tailed Wilcoxon signed-rank test was performed to analyze hydroxyproline levels. Statistical significance was defined as $\mathrm{p}<0.05$.

\section{Results}

A total of 60 adult female Sprague-Dawley rats were used in this study. However, 4 rats were excluded due to perioperative dural tears or hematoma formation. Therefore, the final evaluation was performed on 56 rats (32 rats underwent histopathological examination and 24 were used for biochemical analysis). All animals were active and ambulatory, and none of them showed any neurological deficits according to the Basso-Beattie-Bresnahan scale at the time of euthanization. There was no instance of mortality or morbidity due to anesthesia. No clinical signs of infection or adverse effects were encountered in the skin, fascia, or muscle layers, and all wounds healed uneventfully after surgery.

\section{Histopathological Evaluation}

There was significant concordance on all parameters between 2 observers ( $\kappa$ coefficient $0.754,0.749,0.759$,
$0.429,0.632$, and 0.465 for epidural fibrosis, dural adhesion, fibroblast cell density, medulla spinalis retraction, foreign-body reaction, and granulation, respectively). All of these values were statistically significant ( $\mathrm{p}<0.001$ ). Varied grades of epidural fibrosis were observed in the rats during examination. The sham and control groups had dense epidural fibrosis, while the HA and HA gel groups had minimal epidural fibrosis. Animals treated with HA and HA gel showed a discrete area of hypointense signals between the dura mater and the surrounding muscle tissue and nerve roots (Fig. 1C-F). Epidural fibrosis, granulation tissue, and fibroblast cell density were found to be less in the HA group than in the sham group $(p=0.005, p=0.021$, and $p=0.007$, respectively); these differences were statistically significant. A statistically significant difference was also noted between the HA group and the control group in terms of fibroblast cell density, epidural fibrosis, and dural adhesion ( $\mathrm{p}=0.028, \mathrm{p}=0.007$, and $\mathrm{p}=0.003$, respectively).

Significant differences regarding the granulation tissue, fibroblast cell density, and epidural fibrosis were found between the HA gel group and the sham group $(\mathrm{p}=0.038$, $\mathrm{p}=0.001$, and $\mathrm{p}=0.038$, respectively). Inflammation, foreign-body reaction, dural adhesion, and fibroblast cell density were observed at a significantly less frequency in the HA gel group than in the control group $(\mathrm{p}=0.05, \mathrm{p}=$ $0.025, p=0.005$, and $p=0.005$, respectively). Conversely, no significant differences were found between the HA and HA gel groups $(\mathrm{p}>0.05)$.

In the sham group, Grade 1 epidural fibrosis was demonstrated in 1 rat $(12.5 \%)$; Grade 2 , in 5 rats $(62.5 \%)$; and 
Grade 3, in 2 rats (25\%). Additionally, Grade 0 dural adhesion was observed in 3 rats $(37.5 \%)$; Grade 1 , in 1 rat $(12.5 \%)$; Grade 2 , in 1 rat $(12.5 \%)$; and Grade 3, in the remaining 3 rats $(37.5 \%)$.

In the control group, Grade 1 epidural fibrosis was demonstrated in 1 rat $(12.5 \%)$, and Grade 2 epidural fibrosis was found in the remaining 7 rats $(87.5 \%)$. Furthermore, Grade 1 dural adhesions were found in 1 rat (12.5\%); Grade 2, in 1 rat (12.5\%); and Grade 3, in 6 rats (75\%) (Fig. 1A and B).

In the HA group, Grade 0 epidural fibrosis was demonstrated in 1 rat (12.5\%); Grade 1, in 6 rats $(75 \%)$; and Grade 2, in 1 rat (12.5\%). Moreover, Grade 0 dural adhesions were observed in 4 rats $(50 \%)$; Grade 1 , in 1 rat (12.5\%); and Grade 2, in 3 rats (37.5\%) (Fig. 1C and D).

In the HA gel group, Grade 0 epidural fibrosis was demonstrated in 2 rats (25\%); Grade 1, in 3 rats (37.5\%); and Grade 2, in the remaining 3 rats (37.5\%). Addition-

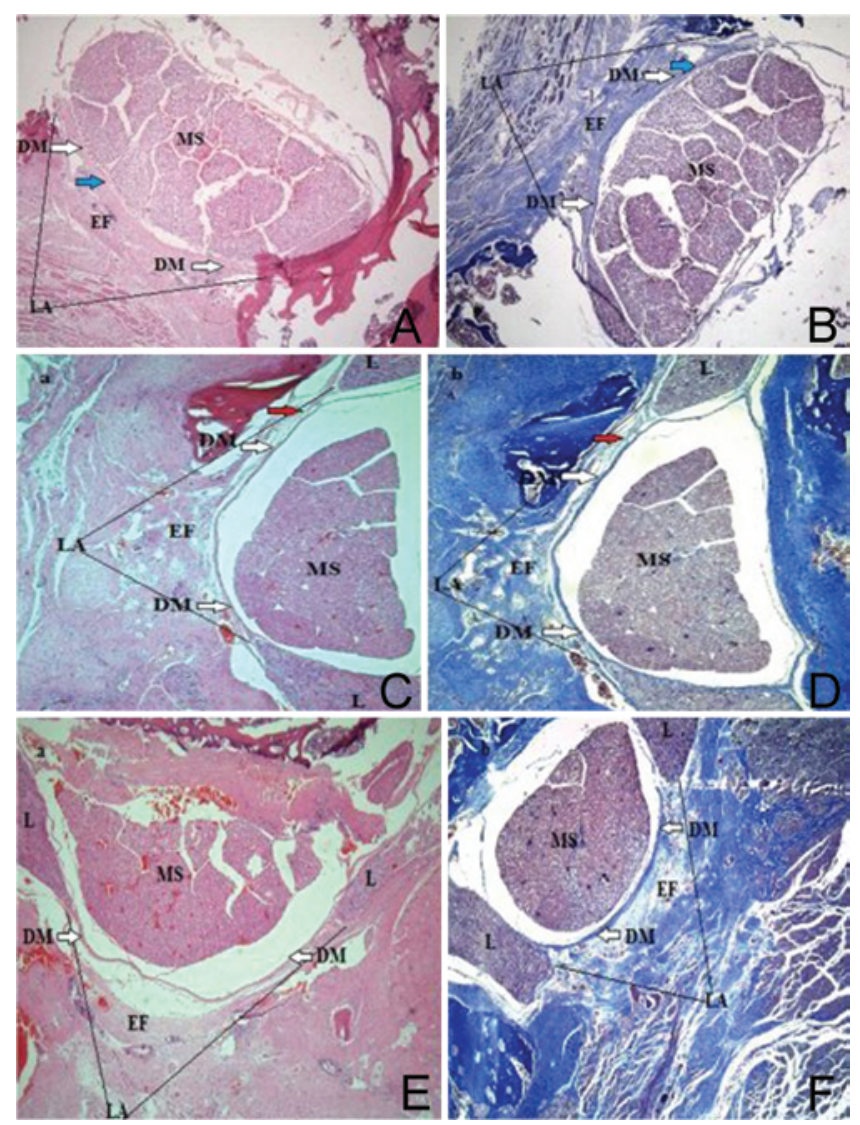

FIG. 1. Photomicrographs. A and B: Grade 3 epidural fibrosis (EF) and dural adhesion in the control group. Dense epidural fibrosis, dural adhesion, and medulla spinalis (MS) retraction (blue arrows) are seen in the laminectomized area (LA). DM = dura mater (white arrows). $\mathrm{C}$ and D: Grade 1 epidural fibrosis and dural adhesion in the HA group. Note that less epidural fibrosis and fibroblast cell density and only thin fibrous bands between dura mater and scar tissue (red arrows) are observed in the laminectomized area. E and F: Grade 1 epidural fibrosis and Grade 0 dural adhesion in the HA gel group. Significantly less epidural fibrosis and fibroblast cell density and a wide space between the dura mater and fibrosis tissue are seen in the laminectomized area. $L=$ lamina. $H$ \& $E$ $(A, C$, and $E)$; Masson's trichrome $(B, D$, and $F)$, original magnification $\times 40(A-F)$. Figure is available in color online only. ally, Grade 0 dural adhesions were found in 1 rat (12.5\%); Grade 1, in 3 rats (37.5\%); and Grade 2, in 4 rats $(50 \%)$. Figure $1 \mathrm{E}$ and $\mathrm{F}$ shows Grade 1 fibrosis and Grade 0 dural adhesions, as observed in the HA gel group.

The fibroblast cell density was calculated in each field by the median fibroblast cell count. No Grade 3 fibroblast cell density was observed in the HA or HA gel groups. In the HA group, Grade 1 fibroblast cell density was observed in 5 rats $(62.5 \%)$ and Grade 2, in 3 rats $(37.5 \%)$; no Grade 3 fibroblast cell density was observed. However, in the HA gel group, Grade 1 fibroblast cell density was demonstrated in 7 rats $(87.5 \%)$, and Grade $2(12.5 \%)$ was demonstrated in the remaining rat. These results showed a statistically significant difference between the fibroblast cell density in the sham and control groups, compared with the HA and HA gel groups $(\mathrm{p}<0.05)$.

Descriptive statistics of the histopathological parameters and intergroup comparisons are presented in Tables $1-3$.

\section{Biochemical Analysis}

The median values of hydroxyproline were $0.396 \mu \mathrm{g} / \mathrm{g}$ wet tissue (range $0.290-0.483 \mu \mathrm{g} / \mathrm{g}$ wet tissue) in the sham group, $0.462 \mu \mathrm{g} / \mathrm{g}$ wet tissue (range $0.273-0.705 \mu \mathrm{g} / \mathrm{g}$ wet tissue) in the control group, $0.542 \mu \mathrm{g} / \mathrm{g}$ wet tissue (range $0.354-1.118 \mu \mathrm{g} / \mathrm{g}$ wet tissue) in the HA group, and 0.582 $\mu \mathrm{g} / \mathrm{g}$ wet tissue (range $0.423-0.762 \mu \mathrm{g} / \mathrm{g}$ wet tissue) in the HA gel group (Fig. 2). On comparing the 4 groups, we found that the hydroxyproline levels were significantly lower in the HA and HA gel groups $(p<0.009)$. Statistically, no difference was found between the sham and control groups $(\mathrm{p}=0.93)$ or between the HA and HA gel groups $(\mathrm{p}=0.18)$ (Fig. 2).

\section{Discussion}

The origins of postoperative fibrosis are multifactorial. Individual variability in the degree of scar formation is one contributing factor. Because the formation of fibrotic tissue is inevitable in every case, its effects on postoperative pain are not exactly understood. ${ }^{39}$ However, it has been demonstrated that fibrotic tissue can cause adhesions among adjacent tissues. Dense fibrotic tissue can lead to the compression of adjacent anatomical structures, dural tethering, immobility, and distortion of the spinal nerve root, thereby resulting in the susceptibility of the spinal root. Furthermore, it has been reported that neuronal atrophy and axonal degeneration can develop beneath the scar tissue. 17,38,39 Although no consensus has been reached on the role of epidural fibrosis in lingering back pain or its efficacy in poor clinical outcomes, fibrosis is known to cause difficulties when the operative areas are reexposed during a second surgery, potentially leading to complications. ${ }^{11}$

Various animal research and clinical studies have revealed that multiple factors are involved in the pathogenesis of epidural fibrosis formation; these include individual variability, postoperative hematoma, laminectomy techniques, anatomical location within the vertebral column, amount of bone removed, and species and race differences. ${ }^{21}$ In our study, a model of laminectomy and discectomy (annular fenestration) was constructed, using 12-week-old 
TABLE 2. Intergroup comparisons of parameters as $p$ values*

\begin{tabular}{lccccccc}
\hline Comparison & $\begin{array}{c}\text { No. of } \\
\text { Rats }\end{array}$ & $\begin{array}{c}\text { Epidural } \\
\text { Fibrosis }\end{array}$ & $\begin{array}{c}\text { Dural } \\
\text { Adhesion }\end{array}$ & $\begin{array}{c}\text { Fibroblast } \\
\text { Cell Density }\end{array}$ & $\begin{array}{c}\text { Medulla Spinalis } \\
\text { Retraction }\end{array}$ & $\begin{array}{c}\text { Foreign-Body } \\
\text { Reaction }\end{array}$ & $\begin{array}{c}\text { Granulation } \\
\text { Tissue }\end{array}$ \\
\hline Sham vs control & 8 & 0.505 & 0.130 & 0.798 & 0.721 & 1.000 & 0.382 \\
\hline Sham vs HA & 8 & $\mathbf{0 . 0 0 5}$ & 0.382 & $\mathbf{0 . 0 0 7}$ & 0.234 & 0.282 & $\mathbf{0 . 0 2 1}$ \\
\hline Sham vs HA gel & 8 & $\mathbf{0 . 0 3 8}$ & 0.798 & $\mathbf{0 . 0 0 1}$ & 0.382 & 0.118 & $\mathbf{0 . 0 3 8}$ \\
\hline Control vs HA & 8 & $\mathbf{0 . 0 0 7}$ & $\mathbf{0 . 0 0 3}$ & $\mathbf{0 . 0 2 8}$ & 0.105 & 0.076 & 0.234 \\
\hline Control vs HA gel & 8 & 0.083 & $\mathbf{0 . 0 0 5}$ & $\mathbf{0 . 0 0 5}$ & 0.195 & $\mathbf{0 . 0 2 5}$ & 0.382 \\
\hline HA vs HA gel & 8 & 0.721 & 0.442 & 0.442 & 0.721 & 1.000 & 0.721 \\
\hline
\end{tabular}

* Values in boldface are significant.

female Sprague-Dawley rats weighing 250-300 g, to assess the relevance of this model compared with other studies.

Many studies have been conducted to investigate the efficacy of various agents in the prevention of fibrosis formation after spinal surgery. ${ }^{2,16}$ However, the materials and methods used previously to prevent epidural fibrosis in laboratory studies have mostly been unsatisfactory in their clinical applicability. Thus, epidural fibrosis continues to be a clinical problem.

Hyaluronic acid is a heteropolysaccharide that naturally occurs in the soft tissues and extracellular matrix of all vertebrates ${ }^{3,30}$ and is completely resorbed in vivo. It is a regulator of many biological events; during the first stages of tissue repair, a relatively high concentration of HA in the extracellular space has been demonstrated to partially limit the extracellular matrix and collagen deposition. ${ }^{28,41}$ Therefore, its role in preventing epidural fibrosis has been frequently investigated. Songer and colleagues ${ }^{42}$ investigated the effects of HA in gel foam and claimed that, in their HA group, a wider distance was observed among the subarachnoid space, fibrotic tissues, and dura mater, in addition to a lower inflammatory cell count in the epidural fibrosis tissue. Kato and associate ${ }^{22}$ used sodium HA in their study to examine the adhesion area and histopathological thickness of the tissue surrounding the nerve roots. They reported a significant decrease in epidural fibrosis formation.

Cross-linked high-molecular-weight HA (HA gel) is derived from pure hyaluronic acid oligomers. ${ }^{29,37} \mathrm{HA}$ gel has been found to be a potent inhibitor of TNF $\alpha$ and TNF $\beta{ }^{7,8}$ Compared with HA, HA gel effectively retards hydrolytic degradation, has less viscosity, remains longer in tissues, and is resorbed via HA's pathways within 7 days. ${ }^{7,44} \mathrm{HA}$ gels have been widely investigated and clinically used in obstetrics, gynecology, abdominopelvic surgery, and or-

TABLE 3. Comparison of inflammation by grade*

\begin{tabular}{llcr}
\hline & \multicolumn{3}{c}{ No. of Rats $(\%)$} \\
\cline { 2 - 4 } Group & Grade 0 & Grade 1 & \multicolumn{1}{c}{ Total } \\
\hline Sham & $1(12.5)$ & $7(87.5)$ & $8(100)$ \\
\hline Control & $0(0)$ & $8(100)$ & $8(100)$ \\
\hline HA & $4(50)$ & $4(50)$ & $8(100)$ \\
\hline HA gel & $5(62.5)$ & $3(37.5)$ & $8(100)$ \\
\hline Total & $10(31.2)$ & $22(68.8)$ & $32(100)$ \\
\hline
\end{tabular}

* Grade 0, inflammation absent; Grade 1, minimal inflammation. thopedics; however, no research has been conducted to investigate its efficacy in epidural fibrosis.

In our study, there was significantly less fibrosis tissue, granulation tissue, and fibroblast cell density in the HA gel group than in the sham group, and there was less dural adhesion formation and fibroblast cell density in the HA gel group compared with the control group; this result supports that HA gel may prevent epidural fibrosis formation after spinal surgery. In particular, the lower fibroblast cell density in the HA gel group than in the HA group (mean cell density, < 50) suggests that the consistency of the fibrotic tissue in the case of the former group will resemble a loose conformation.

Collagen plays a key role in every stage of wound healing due to its regulatory and consolidating function in the formation of new tissues. It has been argued that the amount of collagen deposition in the tissue is related to the amount of fibrotic tissue. ${ }^{24}$ As tissue repairs proceed, hydroxyproline emerges and swiftly accumulates in the collagen. Hydroxyproline levels are consistent with the severity of fibroid degeneration and adhesion. ${ }^{24}$

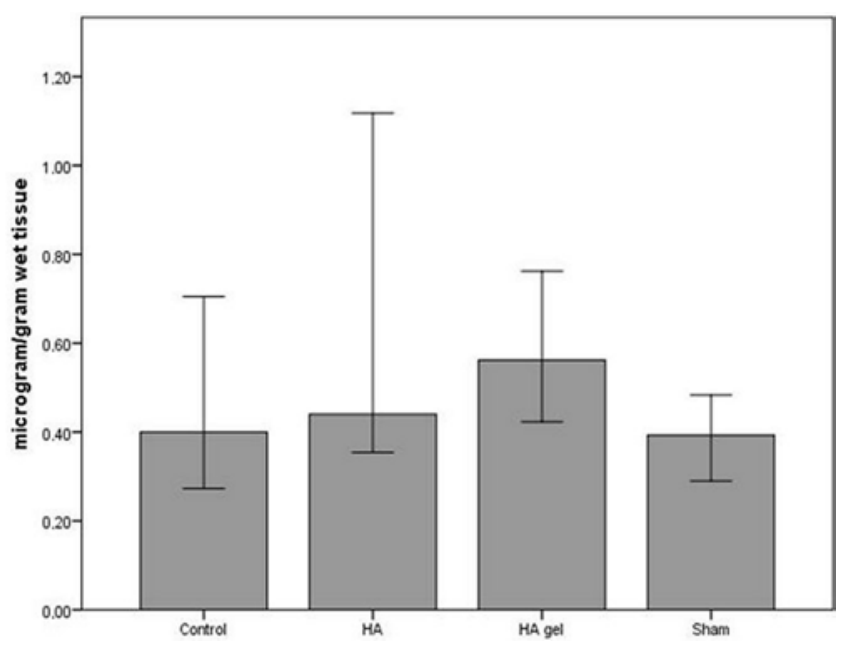

FIG. 2. Graph showing comparisons of the mean values of hydroxyproline levels ( $\mu \mathrm{g} / \mathrm{g}$ wet tissue). Whiskers indicate standard deviation. With regard to the median hydroxyproline levels, the values in the HA and HA gel groups were observed to be significantly lower than those in the sham and control groups. The difference in the values of sham and $\mathrm{HA}$ groups is $p<0.002$; between sham and $\mathrm{HA}$ gel, $p<0.002$; between control and HA groups, $p<0.009$; and between control and HA gel, $p<$ 0.002 . 
Because hydroxyproline level is the best biochemical parameter for assessing the amount of collagen, fibroid degeneration, and wound healing in the tissues, we investigated these levels in our study. The mean hydroxyproline levels in the HA and HA gel groups were found to be significantly lower than those in the sham and control groups. Despite the fact that no statistically significant differences were detected in either the histopathological evaluation or the biochemical analysis between the HA and HA gel groups, both the fibroblast cell density and hydroxyproline levels were lower in the latter group than in the former. The decreases in hydroxyproline levels and in the fibroblast cell density are reflective of reduced fibroid degeneration in the tissues. Our data suggest that HA gel may decrease the pressure exerted by the fibrotic tissue on the adjacent tissues, thereby ameliorating the associated symptoms and risks of complications in case of reoperation.

\section{Conclusions}

This study showed that HA gel is a particularly effective and promising material in the prevention of epidural fibrosis and in the reduction of fibrotic tissue density. Nevertheless, the efficacy of this agent should be further explored in additional experimental and clinical studies.

\section{Acknowledgment}

We thank Nesrin Ugras, MD, for evaluation of the histopathological specimens.

\section{References}

1. Akeson WH, Massie JB, Huang B, Giurea A, Sah R, Garfin SR, et al: Topical high-molecular-weight hyaluronan and a roofing barrier sheet equally inhibit postlaminectomy fibrosis. Spine J 5:180-190, 2005

2. Alkalay RN, Kim DH, Urry DW, Xu J, Parker TM, Glazer PA: Prevention of postlaminectomy epidural fibrosis using bioelastic materials. Spine (Phila Pa 1976) 28:1659-1665, 2003

3. Amara FM, Entwistle J, Kuschak TI, Turley EA, Wright JA: Transforming growth factor- $\beta 1$ stimulates multiple protein interactions at a unique cis-element in the 3 '-untranslated region of the hyaluronan receptor RHAMM mRNA. J Biol Chem 271:15279-15284, 1996

4. Barberá J, Gonzalez J, Esquerdo J, Broseta J, Barcia-Salorio JL: Prophylaxis of the laminectomy membrane. An experimental study in dogs. J Neurosurg 49:419-424, 1978

5. Boot DA, Hughes SP: The prevention of adhesions after laminectomy. Adverse results of Zenoderm implantations into laminectomy sites in rabbits. Clin Orthop Relat Res (215):296-302, 1987

6. Cekinmez M, Sen O, Atalay B, Erdogan B, Bavbek M, Caner $\mathrm{H}$, et al: Effects of methyl prednisolone acetate, fibrin glue and combination of methyl prednisolone acetate and fibrin glue in prevention of epidural fibrosis in a rat model. Neurol Res 32:700-705, 2010

7. Cencetti C, Bellini D, Longinotti C, Martinelli A, Matricardi $\mathrm{P}$ : Preparation and characterization of a new gellan gum and sulphated hyaluronic acid hydrogel designed for epidural scar prevention. J Mater Sci Mater Med 22:263-271, 2011

8. Chang NS, Intrieri C, Mattison J, Armand G: Synthetic polysulfated hyaluronic acid is a potent inhibitor for tumor necrosis factor production. J Leukoc Biol 55:778-784, 1994

9. Choi HJ, Kim KB, Kwon YM: Effect of amniotic membrane to reduce postlaminectomy epidural adhesion on a rat model. J Korean Neurosurg Soc 49:323-328, 2011

10. Colak A, Bavbek M, Aydin NE, Renda N, Açikgöz B: Effect of $\mathrm{CO}_{2}$ laser on spinal epidural fibrosis. Acta Neurochir (Wien) 138:162-166, 1996

11. Davis RA: A long-term outcome analysis of 984 surgically treated herniated lumbar discs. J Neurosurg 80:415-421, 1994

12. de Tribolet N, Porchet F, Lutz TW, Gratzl O, Brotchi J, van Alphen HA, et al: Clinical assessment of a novel antiadhesion barrier gel: prospective, randomized, multicenter, clinical trial of ADCON-L to inhibit postoperative peridural fibrosis and related symptoms after lumbar discectomy. Am J Orthop 27:111-120, 1998

13. DiFazio FA, Nichols JB, Pope MH, Frymoyer JW: The use of expanded polytetrafluoroethylene as an interpositional membrane after lumbar laminectomy. Spine (Phila Pa 1976) 20:986-991, 1995

14. Dogan S, Taskapilioglu O, Sahin S, Korfali E: The effects of Seprafilm and Interceed TC7 on epidural fibrosis in a rat hemilaminectomy model. Neurosurg Q 19:190-195, 2009

15. Doğulu F, Durdağ E, Cemil B, Kurt G, Özgün G: The role of FloSeal in reducing epidural fibrosis in a rat laminectomy model. Neurol Neurochir Pol 43:346-351, 2009

16. Epter RS, Helm S II, Hayek SM, Benyamin RM, Smith HS, Abdi S: Systematic review of percutaneous adhesiolysis and management of chronic low back pain in post lumbar surgery syndrome. Pain Physician 12:361-378, 2009

17. Gerszten PC, Moossy JJ, Flickinger JC, Gerszten K, Kalend A, Martínez AJ: Inhibition of peridural fibrosis after laminectomy using low-dose external beam radiation in a dog model. Neurosurgery 46:1478-1485, 2000

18. He Y, Revel M, Loty B: A quantitative model of postlaminectomy scar formation. Effects of a nonsteroidal antiinflammatory drug. Spine (Phila Pa 1976) 20:557-563, 579-580, 1995

19. Hinton JL Jr, Warejcka DJ, Mei Y, McLendon RE, Laurencin C, Lucas PA, et al: Inhibition of epidural scar formation after lumbar laminectomy in the rat. Spine (Phila Pa 1976) 20:564-570, 579-580, 1995

20. Jacobs RR, McClain O, Neff J: Control of postlaminectomy scar formation: an experimental and clinical study. Spine (Phila Pa 1976) 5:223-229, 1980

21. Kasimcan MO, Bakar B, Aktaş S, Alhan A, Yilmaz M: Effectiveness of the biophysical barriers on the peridural fibrosis of a postlaminectomy rat model: an experimental research. Injury 42:778-781, 2011

22. Kato T, Haro H, Komori H, Shinomiya K: Evaluation of hyaluronic acid sheet for the prevention of postlaminectomy adhesions. Spine J 5:479-488, 2005

23. Lawson KJ, Malycky JL, Berry JL, Steffee AD: Lamina repair and replacement to control laminectomy membrane formation in dogs. Spine (Phila Pa 1976) 16 (6 Suppl):S222S226, 1991

24. Lee CK, Alexander H: Prevention of postlaminectomy scar formation. Spine (Phila Pa 1976) 9:305-312, 1984

25. Lee JY, Ebel H, Friese M, Schillinger G, Schröder R, Klug N: Influence of TachoComb in comparison to local hemostyptic agents on epidural fibrosis in a rat laminectomy model. Minim Invasive Neurosurg 46:106-109, 2003

26. Liu LM, Song YM, Duan H, Ding YL, Lu B: Effect of polylactic acid glue in preventing epidural scar adhesion after laminectomy in rabbits. Chin J Traumatol 9:146-151, 2006

27. Lladó A, Sologaistua E, Guimerá J, Marín M: Expanded polytetrafluoroethylene membrane for the prevention of peridural fibrosis after spinal surgery: a clinical study. Eur Spine J 8:144-150, 1999

28. Longaker MT, Chiu ES, Adzick NS, Stern M, Harrison MR, Stern R: Studies in fetal wound healing. V. A prolonged pres- 
ence of hyaluronic acid characterizes fetal wound fluid. Ann Surg 213:292-296, 1991

29. Mais V, Cirronis MG, Peiretti M, Ferrucci G, Cossu E, Melis GB: Efficacy of auto-crosslinked hyaluronan gel for adhesion prevention in laparoscopy and hysteroscopy: a systematic review and meta-analysis of randomized controlled trials. Eur J Obstet Gynecol Reprod Biol 160:1-5, 2012

30. Massie JB, Schimizzi AL, Huang B, Kim CW, Garfin SR, Akeson WH: Topical high molecular weight hyaluronan reduces radicular pain post laminectomy in a rat model. Spine J 5:494-502, 2005

31. Nussbaum CE, McDonald JV, Baggs RB: Use of Vicryl (polyglactin 910) mesh to limit epidural scar formation after laminectomy. Neurosurgery 26:649-654, 1990

32. Özdemir O, Çalışaneller T, Sönmez E, Kıyıcı H, Caner H, Altinörs N: Topical use of colchicine to prevent spinal epidural fibrosis in rats. Neurol Res 32:1117-1120, 2010

33. Ozer AF, Oktenoglu T, Sasani M, Bozkus H, Canbulat N, Karaarslan E, et al: Preserving the ligamentum flavum in lumbar discectomy: a new technique that prevents scar tissue formation in the first 6 months postsurgery. Neurosurgery 59 (1 Suppl 1):ONS126-ONS133, 2006

34. Park SN, Park JC, Kim HO, Song MJ, Suh H: Characterization of porous collagen/hyaluronic acid scaffold modified by 1-ethyl-3-(3-dimethylaminopropyl)carbodiimide crosslinking. Biomaterials 23:1205-1212, 2002

35. Park YK, Tator CH: Prevention of arachnoiditis and postoperative tethering of the spinal cord with Gore-Tex surgical membrane: an experimental study with rats. Neurosurgery 42:813-824, 1998

36. Pospiech J, Pajonk F, Stolke D: Epidural scar tissue formation after spinal surgery: an experimental study. Eur Spine J 4:213-219, 1995

37. Renier D, Bellato P, Bellini D, Pavesio A, Pressato D, Borrione A: Pharmacokinetic behaviour of ACP gel, an autocrosslinked hyaluronan derivative, after intraperitoneal administration. Biomaterials 26:5368-5374, 2005

38. Rodgers KE, Robertson JT, Espinoza T, Oppelt W, Cortese S, diZerega GS, et al: Reduction of epidural fibrosis in lumbar surgery with Oxiplex adhesion barriers of carboxymethylcellulose and polyethylene oxide. Spine J 3:277-284, 2003

39. Ross JS, Robertson JT, Frederickson RC, Petrie JL, Obuchowski N, Modic MT, et al: Association between peridural scar and recurrent radicular pain after lumbar discectomy: magnetic resonance evaluation. Neurosurgery 38:855-863, 1996

40. Savran M, Bekar A, Cansev M, Tolunay S, Ulus IH, Taskapilioglu MO: Prevention of epidural fibrosis in rats by local or systemic administration of citicoline. Turk Neurosurg 22:634-640, 2012

41. Shih HN, Fang JF, Chen JH, Yang CL, Chen YH, Sung TH, et al: Reduction in experimental peridural adhesion with the use of a crosslinked hyaluronate/collagen membrane. J Biomed Mater Res B Appl Biomater 71:421-428, 2004

42. Songer MN, Ghosh L, Spencer DL: Effects of sodium hyaluronate on peridural fibrosis after lumbar laminotomy and discectomy. Spine (Phila Pa 1976) 15:550-554, 1990

43. Songer MN, Rauschning W, Carson EW, Pandit SM: Analysis of peridural scar formation and its prevention after lumbar laminotomy and discectomy in dogs. Spine (Phila Pa 1976) 20:571-580, 1995

44. Strand V, Baraf HS, Lavin PT, Lim S, Hosokawa H: A multicenter, randomized controlled trial comparing a single intraarticular injection of Gel-200, a new cross-linked formulation of hyaluronic acid, to phosphate buffered saline for treatment of osteoarthritis of the knee. Osteoarthritis Cartilage 20:350-356, 2012

45. Tomihata K, Ikada Y: Crosslinking of hyaluronic acid with water-soluble carbodiimide. J Biomed Mater Res 37:243251,1997

\section{Author Contributions}

Conception and design: Dogan, Isık. Acquisition of data: Isık, Taşkapılıoğlu. Analysis and interpretation of data: Isık, Taşkapılıŏlu, Oz Atalay. Drafting the article: Isık, Taşkapılıŏglu. Critically revising the article: Dogan, Taşkapılıoğlu. Reviewed submitted version of manuscript: Taşkapılıoğlu. Study supervision: Dogan.

\section{Correspondence}

Seref Dogan, Uludag University School of Medicine, Department of Neurosurgery, Görükle, 16059 Bursa, Turkey. email: serefdogan01@yahoo.com. 